\title{
East and Southeast Asia in the World Economy: Issues, Problems and Prospects
}

\author{
EDWARD K.Y. CHEN
}

\section{Hypergrowth in Asia}

Economic growth in the Western Pacific Basin or East and Southeast Asia or the Asian Pacific region which comprises economies running from Korea in the north to Indonesia in the south has been phenomenal in the last two decades. In the 1950s and 1960s, Japan surprised the world with economic growth rates of $10 \%$ or more. In the 1960s and 1970s, Asia's newly industrialized economies (NIEs) which include Hong Kong, Singapore, Taiwan and South Korea demonstrated that they were also able to achieve similar or even greater success in rapid economic growth. Since its opening up in 1977, the economy of China has also been growing at an average rate close to $10 \%$. Of the Asean countries, the rate of economic growth of Thailand and Malaysia has in fact not been slow in the past two decades, attaining an average rate of $6 \%$ to $7 \%$ per annum. The performance of the Thai economy in the past two years has of course been very outstanding, achieving an economic growth rate of $11 \%$ in 1988. Even in the case of the Philippines and Indonesia, their performance has been somewhat better than many developing countries in other parts of the world. These 10 Asian economies mentioned above, viz. China, Japan, the Asian NIEs, and the Asean-4 (Malaysia, Thailand, Indonesia, and the Philippines) are undoubtedly the most dynamic developing economies in the world in the post-war years. In this paper, emphasis will be on these 10 Asian economies, or the Asia-10, in general and with reference to the Asian NIEs in particular.

The economic success of the Asian NIEs is surely the envy of other developing countries and it is the interest of researchers and policy makers to find out whether the experiences of the Asian NIEs can be generalized into a model for other developing countries to follow. As a first step, one would naturally try to look for the special characteristics of the experiences of the Asian NIEs. Interestingly, at least in five aspects the experiences of the Asian NIEs are unconventional in the sense that their experiences were not in line with the prevalent economic thinking at that time. 
First, the development strategy adopted by the Asian NIEs is open-door policy and not self-reliance. Specifically, they encouraged the export of manufactured products and the inflow of foreign capital. Thus, the experiences of the Asian NIEs contradict the thesis of the Neo-Marxian Dependency School that the periphery developing countries will continually be exploited by and be dependent on the core developed countries if developing countries do not withdraw themselves from the international economy. The experiences of the Asian NIEs, on the other hand, demonstrate that integrating with the world economy in trade and investment have contributed significantly to their economic success. Furthermore, the Asian NIEs demonstrate that a developing country can depend on exportorientation instead of import substitution as a strategy for industrialization. This issue will be further discussed later in this paper.

Second, to some extent, the experiences of the Asian NIEs endorse the neo-classical assertion of the superiority of competitive market forces over a protective economic environment. But given initial imperfect market conditions in the developing countries the hands of the governments, with perhaps the exception of Hong Kong, are far from being invisible in the economic development of these economies. In Hong Kong's case, the dominance of the rule of law and the less imperfect initial market conditions perhaps explain the relatively smaller role of the government. But even in Hong Kong's case, the role of the government in infrastructure building and in allocation of land should not be understated. Thus, western observers are largely wrong in their remarks that the success of the Asian NIEs is based on laissez-faire free market forces without government intervention. As a matter of fact, the experiences of South Korea, Taiwan and Singapore (if not Hong Kong), reject the view that government policies cannot overcome market failures because government failures are often even more serious than market failures. If we wish to generalize and sum up the nature of economic policies in the Asian NIEs, it would be appropriate to use the term neo-classical interventionism to describe them.

Third, the experiences of the Asian NIEs provide a counter-example to the Weberian hypothesis about the rise of modern capitalism and Christian ethics. About 80 years ago, the renowned German sociologist, Max Weber, wrote about Christianity and the rise of modern capitalism as well as Confucianism and the underdevelopment of China. But today if we look at the economic powers in the Asian Pacific region, we find that the big dragon Japan and the four little dragons, Hong Kong, Singapore, 
South Korea, and Taiwan share one commonality. They all use chopsticks. Their success story is the success of chopsticks economies. The use of chopsticks symbolises Chinese culture which is fundamentally Confucian values. We can therefore now have doubts about the Weberian hypothesis on the basis of the experiences of the Asian NIEs. This subject matter of culture and economic development is later dealt with in greater detail.

Fourth, it is of interest also to observe that experiences of the Asian NIEs show that political institutions might be an important factor explaining their economic success. But in this case, it is an autocratic political regime which has accompanied the rapid economic growth in these economies, while in the Western countries democratic political institutions go hand in hand with modern economic growth. In this connection, it is of course important to note that it is not autocracy per se that explains economic success; what is important is the presence of a development-oriented "hard" state. It can further be argued that an authoritarian government might be inducive to the early economic development stage if (1) there is the presence of a charismatic ruler, (2) the government aims at the improvement of the people's standard of living as a means of maintaining legitimacy, and (3) the authoritarian government is supported by an efficienct and effective bureaucracy.

Fifth, the experiences of the Asian NIEs also provides a counter-example to the Kuznet inverted-U hypothesis which states that income inequality will increase with economic growth at the early stage and will only decrease at the later stage. Generally speaking, we observe in the Asian NIEs that economic growth and increasing income equality have been achieved concomitantly. In other words, economic growth is not at the expense of equality even at the early stage of economic development. Thus, it is not only that development strategies, cultural values, economic policies, and political institutions are different in the Asian NIEs, compared with other developing countries in the course of economic growth and development. Moreover, even in terms of the consequence of economic growth, the Asian NIEs show that a relatively equal distribution of the fruits of economic growth can be achived right from the very beginning.

These special characteristics of the experiences of economic growth in the Asian NIEs give us some clues to formulate a general model of economic development in the NIEs. 


\section{Export-Oriented Industrialization}

Of the five characteristics of economic growth in the Asian NIEs, the development strategy of openness of the economy in general and exporting manufactured products in particular is certainly the key factor for their economic success. The statistics presented in Table 1 support this assertion.

Table 1. Comparative Economic Performance. Average Annual Growth Rates, 1960-85.

\begin{tabular}{lccc} 
& GNP & $\begin{array}{c}\text { Per Capita } \\
\text { Income }\end{array}$ & $\begin{array}{c}\text { Manufactured } \\
\text { Exports }\end{array}$ \\
\hline Asian NIE-4 & 9.0 & 6.9 & 25.8 \\
ASEAN-4 & 6.0 & 3.9 & 19.6 \\
China & 6.4 & 4.8 & 11.8 \\
South Asia & 4.1 & 1.5 & 11.0 \\
Latin America & 3.9 & 1.7 & 10.5 \\
Africa & 3.2 & 0.7 & 4.2 \\
North America & 3.6 & 2.1 & 14.9 \\
EEC & 3.6 & 2.3 & 12.3 \\
Japan & 6.9 & 4.7 & 16.0 \\
Australia & 3.9 & 2.0 & 11.5 \\
\hline
\end{tabular}

In the past 25 years, the Asian NIEs have enjoyed by far the fastest economic growth in the world, an average annual rate of $9.0 \%$ against $6 \%$ in the Asean-4, 4.1\% in South Asia, 3.9\% in Latin America, and 3.2\% in Africa. Looking at the statistics on the export of manufactured products, we also find that the Asian NIEs had the fastest rate of growth. Of course, this association of rapid economic growth with manufactured export growth is no definite proof of export-led economic growth in the sense that the direction of causation runs from the growth of manufactured exports to the growth of income. But, on the basis of some econometric and time series causality analysis I have done, there is strong evidence that economic growth in the Asian NIEs was export-led. Thus, the Asian NIE phenomenon can simply be described as rapid economic growth on the basis of the export of labor-intensive products such as textile, clothing, consumer electronics, toys, and footwear.

It may seem to be common sense to-day that export-oriented industrialization is a better strategy than import substitution. And indeed it is the teaching of the Classical School that free trade on the basis of each coun- 
try's comparative advantage is the best for everybody and for the world as a whole. But we must bear in mind that in the 1940s, 1950s and even the early 1960s, development economists and policy-makers almost without exception regarded export-oriented industrialization at the early stage of economic development unthinkable. The reason is obvious enough. How can the products of infant industries in a newly developing country be able to compete at world prices with the developed or more advanced developing countries? Import substitution in the form of protecting infant industries behind a high tariff wall was therefore the norm of industrialization strategy. Protectionism is usually accompanied by a low interest rate policy for the encouragement of the use of capital and an overvalued exchange rate for the encouragement of the import of capital goods. All these measures are unfortunately price-distorting. I have classified the stages and types of industrialization into the following:

\section{Import Substitution 1 (IS1),}

producing consumer goods; using protectionist measures to groom infant industries.

2. Import Substitution 2 (IS2), producing capital goods and consumer durables.

3. Export Orientation 1 (EO1), producing labor-intensive light manufactured goods.

4. Export Orientation 2 (EO2) and Export Orientation 2 Complex (EO2 Complex), producing technology, capital, knowledge-intensive industries; developing services, esp. financial; undergoing technological and economic restructuring.

The economic take-off and rapid sustained growth of the Asian NIEs took place during the stage of EO1. But it does not imply that a developing country can leapfrog the import substitution stages all together. The experience of the Asian NIEs, however, suggests that the IS2 stage should be skipped. Both Taiwan and South Korea went through IS1 which certainly laid the foundation for their successful export-oriented growth. Both Taiwan and South Korea however switched to EO1 after a short period of IS2 during which serious difficulties were encountered. This was simply because comparative advantage had yet to be built up in the production of capital and technology intensive products. The experience of the Asian 
NIEs suggests that such a stage of IS2 development should only be attempted after at stage of rapid growth under EO1. Hong Kong and Singapore because of the small size of their domestic markets did not even go through IS1, not to mention IS2. But one must realize that Hong Kong and Singapore are special rather than general cases. Their long period of entrepot trade experience in international marketing serves the purpose of a substitute for IS1 as a precondition for export-oriented growth.

Even if export-orientation is in theory a better development strategy, there is no assurance that a country adopting this policy will experience fast economic growth. On the basis of the five characteristics of the economic growth of the Asian NIEs we can argue that the success of an exportoriented strategy depends on the right kind of economic policies, cultural environment and political institutions. It is therefore of no surprise to us that the economic success of the Asian NIEs has been explained by many on the basis of right economic policies, by some on the basis of cultural values, and by others on the basis of political institutions.

As can be expected, it did not take long for the neo-classical economists to realize that the economic success of the Asian NIEs demonstrates a great victory of neo-classical economics which emphasizes automatic adjustments and free market forces. It is true that the adoption of an exportoriented industrialization strategy implies getting the prices right so that the products can be competitive in the world market. But it is not true that this can be achieved through automatic adjustments. The role of the government has been important in getting the prices right, in setting objectives, and in implementing policies. For example, monopolies have to be destroyed, labor and capital market imperfections have to be removed, overvaluation of exchange rates has to be corrected, trade restrictions have to be reduced, and incentives for exporting have to be established. Thus, what is important is a kind of neo-classical interventionism rather than the invisible hand of the Classical School. But the experience of the Asian NIEs does lend strong support to the classical and neo-classical conviction that competition is better than protection, and therefore export-oriented industrialization is better than import substitution.

But it is certainly no easy task for a developing country to adopt exportoriented industrialization at the early stage of development. As indicated earlier, the role of the government is important. And above all, the response of the people to government policies is even more crucial. If successful economic development is as simple a matter as export-orientation 
and getting the prices right, there would have been very few low income countries left to-day. Besides economics, some begin to believe that there must be some non-economic elements in bringing about the economic success of the Asian NIEs. The cultural factor would of course come to our mind. But as I have said the cultural commonality of the Asian NIEs is Confucian culture which for decades is accepted as an inhibiting rather than moving force for economic development. Thus, one has to have the courage and determination to challenge the academic giant, Max Weber, if one attempts to associate the economic success of the Asian NIEs with Confucianism. The futurologist, Herman Kahn, was the first one who had the courage to explicitly explain the economic success of East Asia on the basis of Confucian ethics in his 1979 book. This was soon echoed by Roderick MacFarquhar and moreover elaborated by Peter Berger in his 1983 address at a conference in Japan. Philosophers, notably Tu Wei-ming and historians like $\mathrm{Yu}$ Ying-shih have given the Confucianism explanation of economic success in East Asia further insights. Following Peter Berger, one gets around Weber's hypothesis by arguing that the old imperial or state Confucianism has evolved gradually over time because of changing political, economic and social circumstances into a new form called vulgar or secular Confucianism which is much more inducive to economic development and the rise of modern capitalism. In essence, the culturalist school has emphasized the following aspects of Confucianism:

1. Work ethics and self-discipline.

2. Hierarchy and obedience.

3. Respect for scholarship.

4. Familism.

5. Thriftiness.

6. Flexibility and adaptability.

The adaptability of entrepreneurs within a Confucian culture can be related to the world attitudes and the dimension of rationalization of Confucianism. Confucianism is world affirmation in the evaluation of the world, uses adaption to the world as the method for pursuit of the highest good, and is cognitive with regard to the dimension of rationalization. Christianity is on the other hand world abnegation, ethical and uses mastery of the world for pursuit of the highest good.

Most recently, political scientists have participated actively in the analy- 
sis of the economic success of the Asian NIEs from their point of view. The beginning of this trend can be traced to a paper by Chalmers Johnson presented at a Conference in early 1984. Johnson attempted to establish a link between political institutions and economic development. This subject of economics and politics is of course not new. But its application to East Asia and Johnson's conclusion that an autocratic government is inducive to economic development are most interesting. It is argued that a development-oriented autocratic "hard " state is necessary for economic development because it provides a stable environment for investment and a machinery for the effective implementation of policies.

Besides these systematic economic, cultural and political theorizations of the economic success of the Asian NIEs, there are also other less formal explanations which emphasize pre-conditions (i.e. Japanese occupation in Taiwan and South Korea, British presence in Hong Kong and Singapore), geographical location, country size, natural resource endowment, etc. However, while these factors might be of some significance, their dominant role has largely been refuted on the basis of historical, empirical and theoretical analysis.

\section{The Chen Model}

The explanations I have just discussed in terms of economics, culture and politics suffer in my view from two weaknesses. First, each theory is a partial explanation in the sense that it does not give due consideration to other factors. Even if it does recognize the significance of other factors, no attempts have been made to show the interactions. Secondly, each theory is supposed to be universally true, applicable to all types and stages of economic development. For example, if Confucianism is inducive to economic development, it does not matter whether it is import substitution or export-oriented industrialization.

In this paper, a model which does not suffer from these two weaknesses is presented. It is an integrated or eclectic model which shows the importance of economic and non-economic factors and how these factors are inter-related. More importantly, it is argued that the take-off and the most rapid growth of the Asian NIEs took place under EO1, i.e. export-oriented industrialization on the basis of labor-intensive manufactured exports, and hence any development model explaining the economic success of the 
Asian NIEs should be confined to the stage of EO1. Any attempt to overgeneralize will invaribly encounter serious difficulties.

The starting point of this model is that in the stage of EO1, the most important factors of production are entrepreneurship and labor. Capital is of course necessary for any production, but is relatively less important because the scale of production is generally medium or small in the stage of EO1. Technology used is of the standardized category and production is not land-intensive because factories can be housed in multi-storey industrial buildings. The characteristics of EO1 can be summarized as (1) exporting labor-intensive manufactured products based on realizing the existing comparative advantage, (2) demand-determined export growth in the sense that exports react passively to what the markets want, (3) continuous export growth is sustained by a process of rapid adaptations of entrepreneurs resulting in rapid product diversification.

Figure 1 A NIC Model under EO1

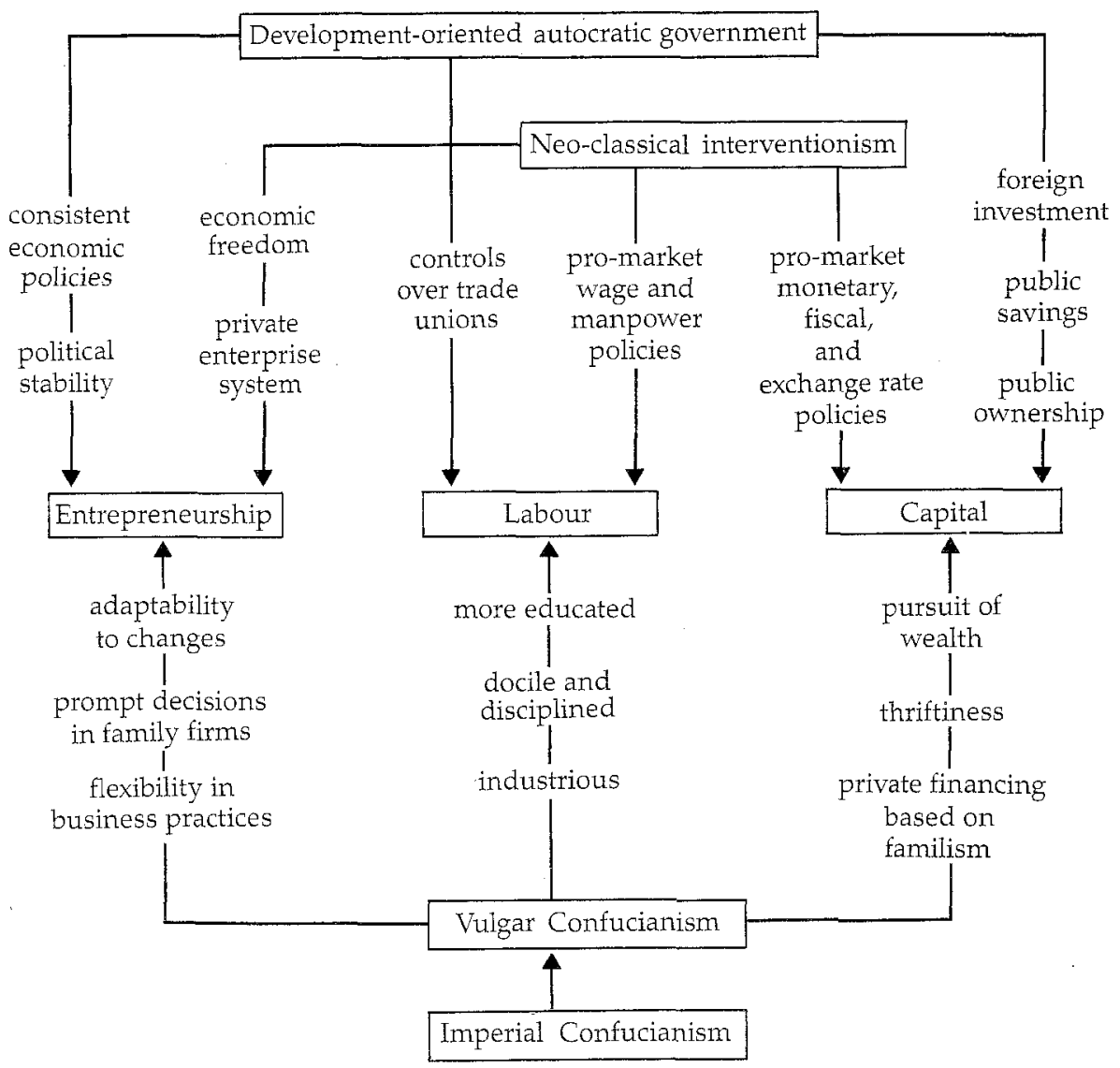


Essentially, the success of EO1 depends on the supply of a class of flexible and adaptable entrepreneurs, the supply of a class of skill and docile labor, and an adequate supply of capital and standardized technology.

The structure of this model illustrated by Figure 1 can be explained in terms of how the interplay of economic and non-economic factors facilitates the type of factor supplies which are essential for the success of EO1.

\section{Entrepreneurship}

1. An autocratic government provides a stable political environment and a set of consistent economic policies for entrepreneurs to grow and to invest.

2. Neo-classical interventionism provides a framework of economic freedom and private enterprise system.

3. Vulgarized Confucianism gives rise to a class of entrepreneurs who are flexible and adaptable. The existence of family. firms enables prompt decisions to be made. Informal (very often verbal) contractual agreement facilitate flexibility and confidentiality in business transactions.

\section{Labor}

1. Only an autocratic government can effectively keep trade unions under control so that wage increases will not increase out of line with increases in labor productivity.

2. Neo-classical interventionism provides a set of policies to ensure the labor market is working under competitive conditions and that no unrealistic minimum wage laws are legislated.

3. Confucian values such as self-discipline, obedience, commitment to work and family, old-age protection dependent on family ties, etc. give rise to an industrious, docile and productive labor force. Moreover, the labor force of Confucian societies has shown to have a higher educational attainment than that in other societies in the developing world. Higher educational standards generally result in greater productivity and adaptability.

\section{Capital}

1. An autocratic government is in a better position to mobilize public savings through schemes such as the central provident fund, and to take 
up public ownership in activities where large capital investment is required. An autocratic government is also in a better position to promote foreign investment by giving concessions to foreign investors in the $a b$ sence of strong opposition parties.

2. Neo-classical interventionism provides a set of competitive market, monetary, fiscal and exchange rate policies which are inducive to domestic saving and capital accumulation.

3. In a Confucian society, thriftiness is a virtue. Moreover, in a society where autocratic government prevails, the pursuit for political excellence is substituted by the pursuit for greater wealth and business excellence. Familism also facilitates the private means of financing investment through pooling resources together; such a means is already adequate for the establishment of small and medium-sized firms.

4. Lastly one would further argue that Confucianism helps reinforce an autocratic government and enhance the supply of able technocrats to the government for the effective implementation of neo-classical interventionist policies.

\section{Prospects}

The Asian NIEs are now in the transition from EO1 to the next stage of development, EO2 and EO2 complex in which capital, technology and knowledge are intensive, produced for both exports and domestic consumption. At the same time, other developing countries in the Asian Pacific region have taken over some of the EO1 industries and have increasingly embarked on the export-oriented industrialization. Nonetheless, these developing countries (Asean-4 and China) have also at the same time engaged in import substitution and the development of agriculture and agro-business industries. This is understandable because of their greater abundance in natural resources than the NIEs.

The questions that remain are (1) whether the Asian NIEs would be able to maintain the past record of rapid growth in their transition to EO2 and/or EO2 complex, and (2) whether the other developing countries in the Asian Pacific region can still count on export-oriented industrialization despite the fact that markets in developed countries will be increasingly difficult to penetrate.

With regard to the Asian NIEs' transition to a higher stage of economic development, one can certainly be optimistic, despite the fact that EO2 
is very different from $\mathrm{EO} 1$ and in consequence the environment inducive to rapid growth under EO1 may no longer be favorable to economic growth under EO2/EO2 complex. The basic differences between EO1 and EO2/EO2 complex are summarized in Table 2.

\section{Table 2. EO1 vs EO2}

Export labor-intensive light manufactured products based om existing comparative advantage

Growth is largely demand-determind

Growth sustained by adaptions (products \& techniques)

Tourism might be of some importance

Capital goods and intermediate products mainly imported
Export capital/technology/knowledgeintensive light and heavy manufactured products based on the acquisition of dynamic comparative advantage

Growth is substantially supplydetermined

Growth sustained by rapid transformations (industries and technology)

Rising importance of the service sector, especially financial services

Some degree of secondary import substitution

In the new stage of development, a different type of neo-classical interventionism is necessary for the acquisition of an economy's dynamic comparative advantage; a class of entrepreneurs of a different calibre is called for to face the problems imposed by a type of economic growth which is based on the supplier's ability to direct the market; and there is the need for a class of entrepreneurs who are not only able to adapt but also to create and transform. Technological creation and transformation and highly trained and educated manpower will become essential for the second stage of export-oriented industrialization. If all these are true, one can no longer have as much optimism as before about the economic future of the Asian NIEs. For instance, Confucianism may be too soft a cultural system to effect transformation; the autocratic political institution may be too closed a system to formulate and implement policies for the emergence of a complex industrial structure.

But we must not fall victim to such a static analysis. The whole world is constantly changing, not to mention that the Asian NIEs have been most dynamic and resilient. We anticipate that political institutions will change and cultural systems will undergo evolutionary processes when the 
economy moves towards a higher stage of development. The political democratization and economic liberalization movements in South Korea and Taiwan are part of this dynamic process. If Confucianism has already evolved once from imperial Confucianism to vulgar Confucianism, there is every reason to believe that it will undergo another evolution to cope with the changing needs of a higher level of export-oriented growth. Thus, from a dynamic point of view there is no reason not to believe that the rapid economic growth of the Asian NIEs can be sustained in the future.

It is more difficult to predict whether domestic reforms and changes in other developing countries in the Asian Pacific region will continue in the right direction to cope with their export-oriented industrialization. But generally speaking, one should have an optimistic outlook for the Asian Pacific economy as a whole. This optimism is usually based on the prediction of the Pacific Century. By the Pacific Century, we mean a shift of the world's centre of economic activities away from the two coasts of the Atlantic to the two coasts of the Pacific. While the prediction of the Pacific Century is now so widely accepted and indeed many people believe that the Pacific Century has already started, very few have given convincing reasons to support why the Pacific Century is coming. As stated above, the economic success of the Asian Pacific region in the last two decades is largely based on export-oriented industrialization. The continued economic prosperity in this region therefore hinges on whether exportoriented industrialization can be spread out to all over the region. In other words, we want to ask the question whether export-oriented industrialization is a zero-sum game. Some economists believe that export-led growth is a zero-sum game, confining to only a few dynamic economies such as the Asian NIEs. The world market, especially in the present age of prevalent protectionism, cannot support the economic growth of all countries in this region based on manufactured exports.

It is, however, comforting to know that in the past few years new developments have taken place in this region such that export-orientedindustrialization in the region as a whole may not be a zero-sum game. For example, Thailand and Malaysia have been growing at relatively high rates on the basis of their more outward looking policies, and yet, there has been no indication that the economic growth of the Asian NIEs has in consequence slowed down. The four major factors explaining a changing international and regional economic environment for the possibility of a positive sum game for export-led economic growth are: (1) an increasing 
degree of complementarity among countries in this region in their industrial production, (2) increased intra-regional trade, (3) increased intraregional investment, and (4) increased opportunity for greater regional economic cooperation.

\section{Flying Geese Pattern of Economic Development}

The increasing degree of complementarity in industrial production among countries in this region can best be explained on the basis of the so-called "Flying Geese" hypothesis. In today's context, we can explain this hypothesis in terms of a group of countries in this region flying together in layers, signifying the different stages of economic development achieved in different countries. The idea is that countries in the higher layer will pass on their out-dated industries to the next layer of countries because of changing comparative advantage over time. Today, this division of labor is not only horizontal in the sense that the entire industry or product is passed on, but also vertical in the sense that the sub-processes may be passed on to other countries in the production of a particular product. In consequence, a regional product is often produced in the sense that the final product goes through production processes in many countries in the region.

Figure 2 Flying Geese Hypothesis

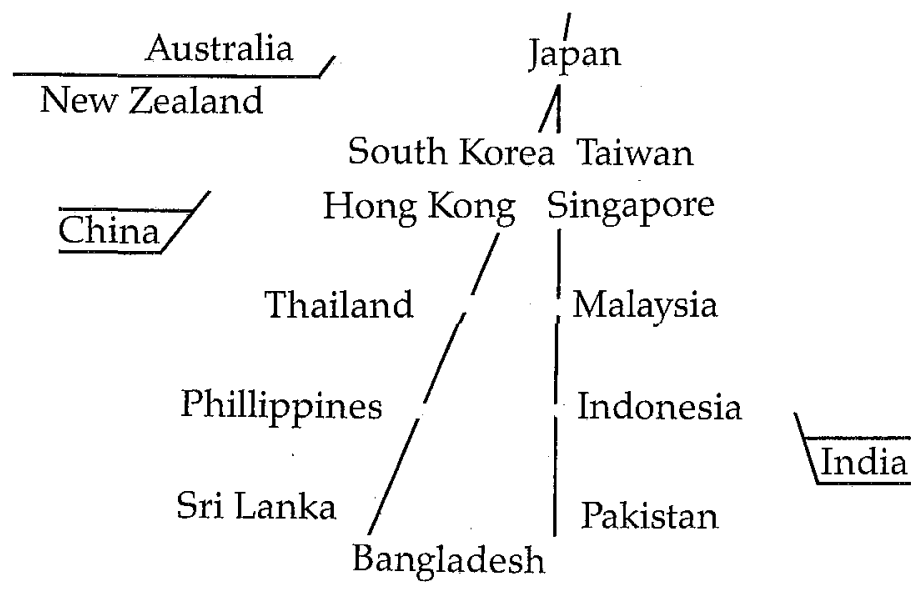

The leader of the flying geese is undoubtedly Japan which is followed by the Asian NIEs. Of the Asean-4, Malaysia and Thailand not only have a 
higher per capita income level than the Philippines and Indonesia, but also a much better economic and political infrastructure for industrialization. In the 1950s, the Philippines had the greatest degree of industrialization but has been falling behind the others in the course of time. China is not a goose but a huge bird flying side by side with the geese. China has the potential of complementing and competing with the various layers of the flying geese at various levels of industrial production. South Asia as a group is far behind the others in the level of development and the degree of industrialization. But India is in much a similar situation as China. It is a big country and has the capability to compete with the developed and more advanced developing countries in many capital and technology intensive productions, and, at the same time, has many labor intensive productions competing with the least advanced developing countries. Industries can be classified into early (food, textile and leather goods), middle (non-metallic minerals, rubber products, wood products, chemical and petroleum refining) and late (for example, clothing, consumer durables, capital and intermediate goods). Now, we can add on top of these three stages of industries the fourth stage, viz. high-tech industries which encompass industries associated with information technology, hi-technology and material sciences. We can envision a flying geese pattern as depicted in Figure 2 and Table 3. China is at present in the early, middle,

\section{Table 3. Stages of Industrial Growth in Asian Pacific Countries}

\begin{tabular}{lll}
\hline Country & \multicolumn{2}{c}{ Stage } \\
\hline Indonesia & Early to middle & Middle to late \\
Philippines & Middle & Late \\
China & Early, middle and late & Late to high-tech \\
Thailand & Middle & Late to high-tech \\
Malaysia & Middle to late & Late to high-tech \\
Hong Kong & Late & Late to high-tech \\
South Korea & Late to high-tech & High-tech \\
Taiwan & Late to high-tech & High-tech \\
Singapore & Late to high-tech & High-tech \\
Japan & High-tech & High-tech \\
\hline
\end{tabular}

and late stages and will be in a late to high-tech stage in the year 2000. South Korea and Taiwan are now ahead of Hong Kong and Singapore in technological capability, and will certainly attain the high-tech stage by the year 2000. It is expected that most of the countries in this region, even 
the less rapidly growing ones, will be able to reach the late stage of industrialization by the year 2000. We can then see that different countries in this region will engage in different stages of industrial development. Even for countries in the same stage of development, specialization is normally possible for achievement of complementarity. When one country graduates in a particular type of production or production process, countries in the next layer will take it over. As a result, the degree of complementarity among countries in the region will increase and the extent of wasteful competition be reduced. Let us take the case of the manufacture of semi-conductors. In the past few years, a very sophisticated pattern of specialization has emerged. Taiwan and South Korea have specialized in wafer fabrication, a production process which is highly capital and technology intensive. Hong Kong and Singapore have become specialized in the design and testing stages which are highly skill and equipment intensive; on the other hand, the Philippines, Thailand and Malaysia concentrate in the assembling stage which is highly labor intensive.

\section{Intra-Regional Trade}

The limitation imposed by overseas markets is certainly the most significant obstacle to export-led economic growth. While it is true that the expansion of world trade has slowed down and the extent of protectionism has increased in most of the developed countries, it is however reassuring to observe that intra-regional trade in the Asian Pacific region has increased significantly in the past few years. In this connection, the following factors will help to enhance further intra-regional trade in the future.

First, the intra-regional market has become larger as a result of the increased income level in the Asian NIEs, the opening up of China, and the restructuring of the Japanese economy. The aggregate GNP of the 4 Asian NIEs, China and Asean-4 will soon come to about one-half of Japan's and should therefore not be underestimated. While the per capita income level of China is very low at only about US $\$ 300$ and the potential of the China market has proved to be a myth rather than reality in the past two hundred years or so, the purchasing power of China's one billion people should now no longer be neglected. This is because the nation-wide average income is misleading as China is a very large country. Along the coast and in the more developed areas, per capita income is in fact very much within the range of the middle income countries in the World Bank classification. For example, many areas along the coast now enjoy a per capita in- 
come of more than US $\$ 1000$. Also, China's consumers are very namebrand and quality conscious. In addition, China has recently opened up its domestic market for foreign production in China. As long as foreign firms operate in China on the basis of converting the local currency at the market rather than the official rate, they have little problem in repatriating its profit out of China. The Japanese market is of course huge in terms of The purchasing power. The problems in the past were related to the inward looking attitude of their consumers and the highly restrictive policies imposed on imports in the form of harsh requirements on standards and specifications. The multi-layer distribution system in Japan has also caused foreign products having no easy entry to the Japanese market. However, the whole situation has changed very drastically. Since 1986, after the appreciation of the yen and the recommendations made in the Maekawa report, Japan has switched from its conventional export-led economic growth to a new form of domestic demand-oriented type of economic growth. It seems that Japan has been able to cope very well with this structural change and it is anticipated that this policy of Japan will continue. Table 4 gives some evidence on the increased import of manufactures by Japan in the past two to three years. Table 5 further shows the drastically increased penetration ratios of some selected products imported by Japan.

Secondly, besides lack of complementarity in the demand for industrial products, an important reason for the lack of growth in intra-regional trade in the past was the protectionist trade policy adopted by the Asian developing countries themselves, especially towards labor intensive consumer products. It is, however, noticed in recent years that a movement of significant liberalization of trade has occured in many of the Asian Pacific countries. In the case of Taiwan and South Korea where huge trade surpluses have been generated in recent years, measures have been taken to lower their tariff rates and liberalize many other trade restrictions. Even in the case of the Philippines, Thailand and Indonesia, we also observe the undertaking of similar measures to remove trade barriers. It is therefore anticipated that in the future, intra-regional trade will increase and the dependence of Asian developing countries on Western markets will decline gradually in relative terms.

\section{Intra-Regional Investment}

Generally speaking, empirical evidence suggests that foreign direct invest- 
Table 4. Import of Japan by Commodity and Region

\begin{tabular}{lrrr}
\hline & \multicolumn{3}{c}{ Value (million. US $\$$ ) } \\
\cline { 2 - 4 } & 1985 & 1986 & 1987 \\
\hline From Asian NIEs & & & \\
Total & 9,839 & 12,519 & 18,812 \\
Manufactured & 5,689 & 7,804 & 12,458 \\
Textiles & 1,563 & 2,206 & 3,594 \\
Chemicals & 498 & 759 & 921 \\
Metal Prod. & 617 & 712 & 1,116 \\
Machinery & 1,271 & 1,687 & 2,818 \\
Others & 1,740 & 2,440 & 4,009 \\
\hline From ASEAN-4 & & & \\
Total & 16,719 & 13,769 & 16,348 \\
Manufactured & 1,398 & 1,481 & 2,220 \\
Textiles & 79 & 97 & 158 \\
Chemicals & 155 & 198 & 208 \\
Metal Prod. & 658 & 496 & 601 \\
Machinery & 150 & 187 & 245 \\
Others & 356 & 503 & 1008 \\
\hline From World & & & \\
Total & 129,539 & 126,408 & 149,515 \\
Manufactured & 40,158 & 52,781 & 65,961 \\
Textiles & 86 & 5,027 & 7,646 \\
Chemicals & 8,073 & 9,733 & 11,845 \\
Metal Prod. & 5,520 & 5,417 & 8,127 \\
Machinery & 12,372 & 14,699 & 19,123 \\
Others & 10,307 & 17,905 & 19,220 \\
\hline
\end{tabular}

Source: Japan Tariff Association, The Summary Report on Trade of Japan (April, 1988).

ment or transnational corporations have played a positive role in the economic development of developing countries in the Asian Pacific region. Traditionally, foreign direct investment in this region comes mainly from the developed countries in the West. Later on, Japanese investment, of course, became important. Most recently, the Asian NIEs have increasingly become important foreign investors in other developing countries in the region. In fact, the direct investment of Japan and the NIEs in this region has been a major factor bringing about a sophisticated sub-regional division of labor in industrial production in this region. Table 6 shows the increasing amount of intra-regional foreign direct investment in this region with special reference to the Japanese and NIEs investment. Although there are at times complaints about the reluctance of Japan to transfer technology, the importance of Japanese investment is undeniable. It is 
Table 4. Import of Japan by Commodity and Region

\begin{tabular}{rrrrrr}
\hline \multicolumn{2}{c}{ Share of Commodity $(\div)$} & & & \multicolumn{2}{c}{ Increasing Rate $(\div)$} \\
\hline 1985 & 1986 & 1987 & & $1985-86$ & $1986-87$ \\
100.00 & 100.00 & 100.00 & & 27.24 & 50.27 \\
57.82 & 62.34 & 66.22 & & 37.18 & 59.64 \\
15.89 & 17.62 & 19.10 & & 41.14 & 62.92 \\
5.06 & 6.06 & 4.90 & & 52.41 & 21.34 \\
6.27 & 5.69 & 5.93 & & 15.40 & 56.74 \\
12.92 & 13.48 & 14.98 & & 32.73 & 67.04 \\
17.68 & 19.49 & 21.31 & & 40.23 & 64.30 \\
\hline & & & & \\
100.00 & 100.00 & 100.00 & & $\div 17.64$ & 18.73 \\
8.36 & 10.76 & 13.58 & & 5.94 & 49.80 \\
0.47 & 0.70 & 0.97 & & 22.78 & 62.89 \\
0.93 & 1.44 & 1.27 & & 27.74 & 5.05 \\
3.94 & 3.60 & 3.68 & & $\div 24.62$ & 21.17 \\
0.90 & 1.36 & 1.50 & & 24.67 & 31.02 \\
2.13 & 3.65 & 6.17 & & 41.29 & 100.40 \\
\hline & & & & \\
100.00 & 100.00 & 100.00 & $\div 2.42$ & 18.28 \\
31.00 & 41.75 & 44.12 & 31.43 & 24.97 \\
3.00 & 3.98 & 5.11 & 29.36 & 52.10 \\
6.23 & 7.70 & 7.92 & 20.56 & 21.70 \\
4.26 & 4.29 & 5.44 & $\div 1.87$ & 50.03 \\
9.55 & 11.63 & 12.79 & 18.81 & 30.10 \\
7.96 & 14.16 & 12.85 & & 73.72 & 7.34 \\
\hline
\end{tabular}

Table 5. Penetration Rate of Selected Products into the Japanese Market

\begin{tabular}{lrlrrr} 
& 80 & $\ldots$ & 85 & 86 & 87 \\
\hline Photo Film & 23.7 & $\ldots$. & 25.8 & 26.9 & 33.0 \\
Auto Tyre & 4.9 & $\ldots$. & 5.6 & 7.7 & 9.0 \\
Fraize (excl. NC) & 24.5 & $\ldots$. & 19.4 & 31.5 & 73.0 \\
Lathe & 20.5 & $\ldots$. & 25.9 & 30.4 & 40.2 \\
35mm Camera & 7.7 & $\ldots$. & 15.7 & 19.7 & 46.6 \\
Calculator & 12.9 & $\ldots$. & 9.8 & 31.0 & 34.0 \\
Telephone & - & $\ldots$. & 10.5 & 9.0 & 13.2 \\
Radio & 25.9 & $\ldots$. & 23.9 & 25.7 & 37.4 \\
Radio Casette & 4.6 & $\ldots$. & 3.8 & 15.3 & 47.5 \\
B\&W TV & 1.5 & $\ldots$. & 1.2 & 14.3 & 54.4 \\
VTR & - & $\ldots$. & 1.7 & 0.4 & 2.7 \\
Electric Fan & 21.6 & $\ldots$. & 25.4 & 30.1 & 54.8 \\
\hline
\end{tabular}

Note: Penetration Rate $=$ Imports/Domestic Demand (Quantum Basis) 
Table 6. Direct Investment to ANIEs and ASEAN from Japan and ANIEs

\begin{tabular}{|c|c|c|c|c|c|c|c|c|}
\hline $\begin{array}{l}\text { Host } \\
\text { Countries }\end{array}$ & $\begin{array}{l}\text { Coun } \\
\text { Year }\end{array}$ & $\begin{array}{l}\text { es of Or } \\
\text { Total }\end{array}$ & Japan & $\begin{array}{l}\text { Sub- } \\
\text { total }\end{array}$ & $\begin{array}{r}\begin{array}{r}\text { Rep. } \\
\text { of } \\
\text { ANICs }\end{array} \\
\end{array}$ & $\begin{array}{r}\text { Tai- } \\
\text { wan } \\
\text { Korea } \\
\end{array}$ & $\begin{array}{c}\text { Singa- } \\
\text { pore }\end{array}$ & $\begin{array}{c}\text { Hong } \\
\text { Kong }\end{array}$ \\
\hline $\begin{array}{l}\text { Rep. of } \\
\text { Korea }\end{array}$ & $\begin{array}{l}1984 \\
1985 \\
1986 \\
1987 \\
\end{array}$ & $\begin{array}{r}422 \\
532 \\
354 \\
1,060 \\
\end{array}$ & $\begin{array}{l}165 \\
360 \\
138 \\
494 \\
\end{array}$ & $\begin{array}{r}4 \\
13 \\
13 \\
69 \\
\end{array}$ & & 2 & 24 & $\begin{array}{r}4 \\
13 \\
13 \\
43 \\
\end{array}$ \\
\hline Taiwan & $\begin{array}{l}1984 \\
1985 \\
1986 \\
1987 \\
\end{array}$ & $\begin{array}{r}519 \\
661 \\
706 \\
1,345^{*} \\
\end{array}$ & $\begin{array}{l}114 \\
145 \\
253 \\
421^{*}\end{array}$ & (n.a.) & (n.a.) & & (n.a.) & (n.a.) \\
\hline $\begin{array}{l}\text { Singa- } \\
\text { pore }\end{array}$ & $\begin{array}{l}1984 \\
1985 \\
1986 \\
1987 \\
\end{array}$ & $\begin{array}{l}626 \\
411 \\
546 \\
775^{\star} \\
\end{array}$ & $\begin{array}{r}78 \\
111 \\
227 \\
317^{*} \\
\end{array}$ & (n.a.) & (n.a.) & (n.a.) & & (n.a.) \\
\hline $\begin{array}{l}\text { Sub- } \\
\text { total } \\
\text { ANIEs } \\
\div \mathrm{HK} \text {. }\end{array}$ & $\begin{array}{l}1984 \\
1985 \\
1986 \\
1987 \\
\end{array}$ & $\begin{array}{l}1,567 \\
1,064 \\
1,606 \\
3.180 \\
\end{array}$ & $\begin{array}{r}357 \\
616 \\
618 \\
1.232 \\
\end{array}$ & (n.a.) & (n.a.) & (n.a.) & (n.a.) & (n.a.) \\
\hline $\begin{array}{l}\text { Philli- } \\
\text { pines }\end{array}$ & $\begin{array}{l}1984 \\
1985 \\
1986 \\
1987 \\
\end{array}$ & $\begin{array}{r}234 \\
132 \\
78 \\
137^{*} \\
\end{array}$ & $\begin{array}{l}34 \\
26 \\
22 \\
24^{*} \\
\end{array}$ & $\begin{array}{r}13 \\
6 \\
7 \\
20^{*} \\
\end{array}$ & $\begin{array}{l}\overline{-} \\
\overline{1^{*}}\end{array}$ & $\begin{array}{c}1 \\
1 \\
4^{*} \\
\end{array}$ & $\begin{array}{c}2 \\
2 \\
- \\
1^{*}\end{array}$ & $\begin{array}{r}10 \\
3 \\
7 \\
14^{*} \\
\end{array}$ \\
\hline Malaysia & $\begin{array}{l}1984 \\
1985 \\
1986 \\
1987 \\
\end{array}$ & $\begin{array}{l}117 \\
131 \\
203 \\
298 \\
\end{array}$ & $\begin{array}{l}29 \\
33 \\
23 \\
92 \\
\end{array}$ & $\begin{array}{r}23 \\
30 \\
49 \\
112 \\
\end{array}$ & $\begin{array}{l}3 \\
4 \\
1 \\
1 \\
\end{array}$ & $\begin{array}{r}- \\
- \\
47 \\
\end{array}$ & $\begin{array}{l}16 \\
19 \\
35 \\
53 \\
\end{array}$ & $\begin{array}{r}4 \\
7 \\
11 \\
11 \\
\end{array}$ \\
\hline Thailand & $\begin{array}{l}1984 \\
1985 \\
1986 \\
1987 \\
\end{array}$ & $\begin{array}{l}407 \\
161 \\
262 \\
686^{*} \\
\end{array}$ & $\begin{array}{r}109 \\
56 \\
116 \\
295^{*} \\
\end{array}$ & $\begin{array}{r}64 \\
\div 11 \\
56 \\
139^{*} \\
\end{array}$ & $\begin{array}{l}- \\
- \\
8^{*}\end{array}$ & $\begin{array}{r}2 \\
6 \\
5 \\
126^{*} \\
\end{array}$ & $\begin{array}{r}47 \\
\div 41 \\
15 \\
4^{*} \\
\end{array}$ & $\begin{array}{c}15 \\
24 \\
36 \\
1^{*} \\
\end{array}$ \\
\hline Indonesia & $\begin{array}{l}1984 \\
1985 \\
1986 \\
1987 \\
\end{array}$ & $\begin{array}{r}1,107 \\
859 \\
826 \\
1,468 \\
\end{array}$ & $\begin{array}{l}112 \\
127 \\
329 \\
524 \\
\end{array}$ & $\begin{array}{r}55 \\
102 \\
159 \\
283 \\
\end{array}$ & $\begin{array}{l}-\overline{52} \\
13^{*} \\
23 \\
\end{array}$ & $\begin{array}{c}3^{*} \\
-70^{*} \\
125 \\
\end{array}$ & $\begin{array}{l}4^{*} \\
\frac{1}{1 *} \\
1\end{array}$ & $\begin{array}{r}48^{*} \\
50^{*} \\
75^{*} \\
134 \\
\end{array}$ \\
\hline $\begin{array}{l}\text { Sub- } \\
\text { total } \\
\text { ASE- } \\
\text { AN } \\
\end{array}$ & $\begin{array}{l}1984 \\
1985 \\
1986 \\
1987 \\
\end{array}$ & $\begin{array}{l}1,865 \\
1,283 \\
1,369 \\
2,589 \\
\end{array}$ & $\begin{array}{l}284 \\
242 \\
490 \\
935 \\
\end{array}$ & $\begin{array}{l}155 \\
127 \\
271 \\
554 \\
\end{array}$ & $\begin{array}{r}3 \\
56 \\
14 \\
33 \\
\end{array}$ & $\begin{array}{r}6 \\
7 \\
77 \\
302 \\
\end{array}$ & $\begin{array}{r}69 \\
\div 20 \\
51 \\
59 \\
\end{array}$ & $\begin{array}{r}77 \\
84 \\
129 \\
160 \\
\end{array}$ \\
\hline Total & $\begin{array}{l}1984 \\
1985 \\
1986 \\
1987 \\
\end{array}$ & $\begin{array}{l}3,432 \\
2,887 \\
2,975 \\
5,769 \\
\end{array}$ & $\begin{array}{r}641 \\
858 \\
1,108 \\
2,167 \\
\end{array}$ & (n.a.) & (n.a.) & (n.a.) & (n.a.) & (n.a.) \\
\hline
\end{tabular}

Note: * denotes "estimates"

Sources: Republic of Korea: Approval Basis, Ministry of Finance

Taiwan Area: Investment Commision, Ministry of Economic Affairs

Singapore: Investment Commitment Basis, Economic Delveopment Board Philippines: Approval Basis, Board of Investment

Malaysia: Approval Basis, Malaysian Industrial Development Authority

Thailand: Net Flow of Direct Investment, Bank of Thailand

Indonesia: Approval Basis, Board of Investment 
however often overlooked that the Asian NIEs are also very important agents of technology transfer in this region. The technology transferred by the NIEs is probably more appropriate for other developing countries in this region. As a result of the changing pattern of comparative advantage and the need of the NIEs to phase out and relocate many of the conventional industries, foreign direct investment of the NIEs in other Asian developing countries will surely increase over time. Similarly, Japan has to relocate many of its industries as a result of the drastic appreciation of the yen and also to recycle its trade surpluses.

\section{Regional Economic Cooperation}

The movement of economic cooperation in the Asian Pacific region started relatively late, compared with other regions. Today, the only formal organization is the Asean consisting of just six member countries. In the 1980s, other informal economic cooperation organizations have emerged. These include the PECC (Pacific Economic Cooperation Conference) and the PBEC (The Pacific Basin Economic Council). The former is too large an organization that it has remained to be an issue deliberating rather than policy formulating body. The latter is too much a business oriented organization. The lack of economic cooperation in the Asian Pacific region in the past should not be a surprise to us in view of the fact that there were very significant differences among countries in this region in terms of history, culture, economic strategies adopted, economic system, and the level of income and the stage of economic development. In addition, for those countries which are export-oriented, the external relations are usually extra-regional biased because of the dominance of Western trading partners or because of the relationship with their former sovereign countries.

Significant changes have however occured in the past few years. Notably, a tendency in the convergence of different economic systems and development strategies adopted can be observed. Specifically, we observe a trend of liberalization, deregulation, and privatization in most countries in this region. At the same time, an increasing number of countries have switched to outward looking policies of industrialization. As a result, the differences in the type and level of economic development have become smaller among countries. With the development of a sub-regional division of labor and an increased intra-regional trade and investment, the degree of inter-dependence among countries has become much greater. Above all, the Asian Pacific developing countries are facing a common external 
economic threat. The emergence of greater protectionism against the export of developing countries, and regionalism in the form of trading blocks has made it necessary for the Asian developing countries to have a closer cooperation and coordination among themselves so that their bargaining power can be enhanced when they have to deal with such trading blocks. It is therefore anticipated that a greater degree of economic cooperation will occur in this region. Some kind of formal organizations consisting most of Western Pacific Rim countries and focussing on trade and investment issue will emerge. At the same time, Taiwan, Mainland China and Hong Kong will become a de facto economic block which can be labelled as "the Greater China", in view of their rapidly increasing economic interaction in trade and investment and their high degree of complementarity in their economic resources. In consequence, Asian Pacific countries as a whole will be able to play a much more important part not only in international trade and investment, but also in the coordination of macroeconomic policy for the international economy.

\section{Final Remarks}

On the basis of the analyses presented above, there is little question that the global and regional economic environment is favorable to the further rapid economic growth and development in the Asian Pacific region as a whole and in the Asia-10 in particular. What is still in question is perhaps whether domestic developments will continue and move in the right directions.

Edward K. Y. Chen is Professor and Director of the centre of Asian Studies, university of Hong Kong.

\section{References}

B. Balassa, The Newly Industrializing Countries in the World Economy (New York: Pergamon Press, 1981).

P. Berger, "Secularity: East and West," in Cultural Identity and Modernization in Asian Countries: Proceedings of Kokugakuin University Centennial Symposium (Tokyo: Institute for Japanese Culture and Classics, Kokugakuin University, 1983). 
M. Bienefeld, "Dependency and the Newly Industrializing Countries: Towards a Reappraisal," in Dudley Seers, ed., Dependency Theory: A Critical Reassessment (London: Frances Pinter, 1981).

E.K.Y. Chen, "The Empirical Relevancy of the Endogenous Technical Progress Function," Kyklos, No. 2 (1976).

E.K.Y. Chen, "Factor Inputs, Total Factor Productivity and Economic Growth: the Asian Experience," The Developing Economies (June 1977).

E.K.Y. Chen, "Domestic Saving and Capital Inflow in Some Asian Countries: A Time-Series Study," Asian Survey (July 1977).

E.K.Y. Chen, Hyper-Growth in Asian Economies (London: Macmillan, 1979).

E.K.Y. Chen, "Export Expansion and Economic Growth in Some Asian. Countries: A Simultaneous-equation Model," in R.C.O. Matthews, ed., Measurement, History, and Factors of Economic Growth (London: Macmillan, 1980).

E.K.Y. Chen, "The Newly Industrializing Countries in Asia: Growth, Experience and Prospects," in R.A. Scalapino, ed., Asian Growth (Berkeley, Institute of East Asian Studies, 1985).

E.K.Y. Chen, "Export-led Economic Development in Chinese Societies: The Existence and Transferability of the NIC Model," paper presented at the Symposium on Economic Development in Chinese Societies, Hong Kong, December 1986; to be published by the Hong Kong University Press.

E.K.Y. Chen, "Economic Development and Technological Revolution," in Productivity Through People in the Age of Changing Technology (Tokyo: Asian Productivity Organization, 1987).

E.K.Y. Chen, "Industrial Development. Foreign Direct Investment and Economic Co-operation: A Study of the Electronics Industry in the Asian Pacific," paper presented at ESCAP Seminar Economic Co-operation Through Foreign Investment, Bangkok, May 1987. 
E.K.Y. Chen, "The Newly Industrializing Countries as Exporters of Technology in Asia-Pacific," in Fu-Chen Lo \& Kamal Salih, eds., The Challenge of Asia-Pacific Co-Operation (ADIPA, Kuala Lumpur, 1987).

E.K.Y. Chen, "Economic Development under Export-Oriented Industrialization: the Asian Experience," paper presented at Conference on Comparative Development Experiences in Asia and Latin America, April 1988, East-West Center, Honolulu.

E.K.Y. Chen, "The Changing Role of the Asian NICs in the Asian Pacific Region towards the Year 2000," in M. Shinohara \& Fu-Chen Lo, eds., Global Adjustment and the Future of Asian-Pacific Economy (Institute of Developing Economics, Japan, 1989).

V. Corbo, et. al., eds., Export-oriented Development Strategies: The Success of the Five NICs (Boulder: Westview, 1985).

W. Galenson, Foreign Trade and Investment: Economic Growth in the Newly Industrializing Asian Countries (Madison: University of Wisconsin Press, 1985).

S. Haggard, "The NICs in the International System," World Politics (January 1986).

G.L. Hicks \& S.C. Redding, "The Story of the East Asian Economic Miracle: The Culture Connection," Euro-Asia Business Review, No. 4 (1983).

R. Hofheinz \& K.E. Calder, The Eastasia Edge (New York: Basic Books, 1982).

C. Johnson, MiTi and the Japanese Miracle (Stanford: Stanford University Press, 1982).

C. Johnson, "Political Institutions and Economic Performance: The Government- Business Relationship in Japan, South Korea, and Taiwan," in R.A. Scalapino, ed., Asian Economic Development (1985).

H. Kahn, World Economic Development: 1979 and Beyond (Boulder: Westview 
Press, 1979).

W. Kraus \& W. Lutkenhorst, The Economic Development of the Pacific Basin (St. Martin's Press, New York, 1986).

S. Kuznets, "Economic Growth and Income Inequality," American Economic Review (March 1955).

R. MacFarquhar, "The Post-Confucian Challenge," The Economist, February $9,1980$.

M. Morishima, Why Has Japan "Succeeded"? (London: Cambridge University Press, 1981).

G. Ranis, "Can the East Asian Model of Development be Generalized: A Comment," World Development, No. 4 (1985).

J. Riedel, "Economic Development in East Asia: Doing What Comes Naturally?", paper presented at ANU Industrialization Workshop, 1985.

Tu Wei-Ming, Confucian Ethics Today: The Singapore Challenge (Singapore: Federal Publications, 1984).

L. Turner \& N. McMullen, The Newly Industrializing Countries: Trade and Adjustment (London: George Allen \& Unwin, 1982).

M. Weber, The Protestant Ethic and the Spirit of Capitalism (Trans. Talcott Parsons) (New York: Schribner, 1930; German original 1905). 